\section{BLOOD GROUPS AND ANTHROPOLOGY}

$\mathrm{R}$ ESEARCH into the distribution of the blood groups has progressed rapidly in recent years, and there has been a growing feeling among anthrop. ologists, serologists and geneticists that this field of joint effort should receive more definite recognition than it has had in the past. An important stage in such recognition was reached when about one hundred and fifty workers in these three branches of science attended a symposium on "Blood Groups and Anthropology", organized by the Royal Anthropological Institute, and held at the Galton Laboratory, University College, London, on March 17.

The chair at the morning session was taken first by Prof. H. J. Fleure, and then by Dr. J. C. Trevor.

Prof. R. A. Fisher, introducing the subject, expressed his pleasure at addressing a meeting in his old Department, and at seeing present several of those who collaborated in his early work on human blood-group genetics. He said that when he began his work, there was still some general reluctance to accept the surprising discovery that the differences between brothers and sisters might be of the same kind as those between different races of a species or even between different species. In his approach to human genetics he was influenced by the pioneer work of Todd, who first showed the extreme complexity of the blood-group systems in cattle. Thanks to the generosity of the Rockefeller Foundation it became possible to set up a serological unit in the Department, in the charge of the late Dr. G. L. Taylor, a unit which later acquired an independent existence as the Galton Laboratory Serum Unit when it moved to Cambridge and carried on special war work under Dr. Taylor, and later under Dr. R. R. Race. Since the genetics of the $A B O$ blood-group system were first established, new human-blood groups and other genetical factors of classificatory value have continued to be discovered at an ever-increasing rate, each in turn gradually becoming available as an anthropological tool. Prof. Fisher said he anticipated that in the next twentyfive years many more such racial discrimina would be placed in the hands of anthropologists.

Dr. C. D. Darlington, speaking on "Blood Groups and Mating Groups", pointed out that man is unique among living species in that almost complete distribution maps can be prepared for some of his genes, namely, those determining the blood groups. In Europe there is a remarkable accord between the frequency map of the blood group $O$ gene and a map showing the ability to pronounce the th sound in modern and historical times. This has demonstrated the genetic control of linguistic development by racial groups.

The usual isogene maps covering large areas illustrate clines resulting from population movements and the consequent spreading of genes. We should, however, expect that, under settled conditions, inbreeding and genetic drift would superimpose on the smooth clines a minor pattern of local fluctuations. The uniquely extensive and detailed records of the blood transfusion services of Great Britain might have been expected to reveal such patterns if subjected to minute topographical analysis, and recent work has shown that they, in fact, do so. This dependence of the distribution of physical characters upon breeding habits affords a meeting place for physical and social anthropology.

The methods and results of $a$ detailed analysis of the records of the National Transfusion Service for the three northern counties of England and the North Riding of Yorkshire were then described by Dr. J. A. Fraser Roberts. He first referred to previous work in Great Britain. He himself in the west of England found no significant fluctuations in bloodgroup frequencies, but he did not subdivide this area anything like as finely as he did the north. $\mathrm{He}$ then turned to his recent work and described how he had analysed the record eards of some 51,000 donors in the north of England by means of a Hollerith punch-card system. The records of individuals were combined on a topographical basis into groups of not less than twenty individuals. These groups were then further combined on a basis of blood. group frequencies into areas separated so far as possible by natural or important artificial features, such that the whole of the significant variation lay between areas and none of it within areas. This sufficed to define nineteen areas with $A$ gene frequencies varying from $19 \cdot 0$ to $32 \cdot 2$ per cent. For the $B$ gene, with its general low frequency, the analysis had to be less detailed, but fifteen areas were defined, with $B$ gene frequencies from $4 \cdot 3$ to 7.9 per cent. The resulting patterns for the whole area are relatively simple.

In contrast to the relatively small local fluctuations, probably of historically recent origin, in the north of England, are the wide and very ancient variations described for Wales and the Marches by Dr. I. M. Watkin. Dr. Watkin explained how, in the course of his work as a transfusion officer, he had been able to question blood donors with Welsh names, ascertaining their place of birth and the maiden names of married women. He analysed topographically the blood-group data of all those who were born with Welsh names and so obtained a picture of the distribution of the blood groups in the Welsh people, uninfluenced by the effects of recent immigration. High $O$ frequencies were found throughout most of North Wales, and very high frequencies along the north coast and the northern part of the west coast. In South Wales, high $O$ frequencies are mainly confined to a few mountain areas. Thus it appear:s that high group-O frequencies are characteristic of an old population in the less accessible mountain areas and high $A$ frequeneies represent relatively recent immigration.

Similar high $O$ frequencies are found not only in Scotland, Ireland and Iceland, but also in various areas in southern Europe and among certain Berber tribes in north Africa. In this connexion, Dr. Watkin pointed out that there is an important pre-Aryan element in Welsh syntax, and that the structure of the Welsh language is held by some philologists to show a remarkable similarity to that of the languages of the white peoples of north Africa.

Some years ago, Prof. Fleure demonstrated the existence, in certain remote moorland areas, of skeletal types resembling those of late palæolithic man. In precisely those areas there are found very high frequencies of blood-group $B$, higher than anywhere else nearer than eastern Poland. Thus the $B$ gene, once supposed to have first entered Europe during the Christian era, is, in fact, abundantly present in populations which are among the oldest found anywhere on the Continent and its islands. 
High $A$ frequencies, resembling those of Scandinavia, have been found in the Gower Peninsula of Pembrokeshire and near the mouth of the River Dee, where there is other evidence of Viking settlement; and there is genetical evidence of a similar component in Anglesey and near the mouths of the Rivers Clwyd and Conway. Near the English border interesting patterns of interpenetration can be traced between the Welsh with a high $O$ frequency and the AngloSaxons with relatively high $A$.

Dr. A. E. Mourant then described "Recent Ad. vances in Serological Anthropology", expressing his intention of summarizing the distribution of the blood groups in those parts of Europe and the world not covered by previous speakers. He exhibited new $A B O$ - and $R h$-gene frequency maps of Europe, of which the former can readily be interpreted in terms of a succession of waves of population moving from east to west, mentioned by Drs. Darlington and Watkin.

The distribution of the $R h$ chromosomes, or gene triplets, he said, is remarkably uniform over the whole of northern and central Europe, with about 40 per cent of $c d e$, the main $R h$-negative combination. The Basques, with more than 50 per cent of cde, possibly represent the original source of most of the chromosomes of this type. In the Mediterranean area, cde is much less common, while CDe rises to about 60 per cent. At the same time, the $R h$-blood groups enable one to trace many details of mixing of a basic Mediterranean population with northern, Basque and Negro components. Recent unpublished discoveries of Dr. D. Messerlin suggest that the Berbers of the Great Atlas Mountains are closely related to the Basques.

In tropical Africa, we again find a very uniform $R h$ distribution, with about 60 per cent of $c D e$ and 20 per cent of cde. The distribution of the $A B O$. and $R h$-groups and of the congenital blood anomaly characterized by sickle-shaped red cells all point to the Pygmies of central Africa as representing one of the two or three major components which enter into the composition of the peoples of Africa as a whole.

Throughout eastern Asia, the Pacific Islands and among the aborigines of Australia and America, the CDe chromosome is dominant, with rather a high frequency of $c D E$ in Maoris and American Indians.

The $M N$-groups have, on the whole, yielded less information of anthropological value than the $A B O$. and $R h$-groups. The most striking feature which they show is a sudden drop from a high to a low $M$ frequency in passing from Java to the rest of Indonesia, the division approximately following Wallace's line.

The blood-group antigen Duffy, recently discovered by Miss M. Cutbush, Dr. P. L. Mollison and Dr. D. M. Parkin, shows the widest possible variations in frequency and will be of great anthropological value when sufficient serum becomes available. The even more recent discovery of the Kidd antigen, by Dr. F. Allen, of Boston, Mass., also promises to be of use in anthropology, as Miss E. W. Ikin has just found it to be much commoner in Negroes than in Europeans.

The American Indians and Eskimos show a general resemblance in their $R h$-groups to the peoples of eastern Asia and the Pacific rogion, but the Americans have much higher $M$ frequencies and, apart from the Alaskan Eskimos, were probably originally completely lacking in $B$, which is common in eastern
Asia and present in most Pacific island peoples. Dr. Mourant said that it is hoped that detailed bloodgroup research in eastern Siberia will one day be possible, for it may throw important light on the origin of the Pre-Columbian Americans.

A series of diagrams illustrating blood-group geneties was exhibited by Drs. R. R. Race and Ruth Sanger.

The afternoon meeting, with Miss M. L. Tildesley in the chair, took the form of a discussion on the organization of investigations in blood-group anthropology. Prof. H. J. Fleure suggested the formation of a co-ordinating centre for such work, under the ægis of the Royal Anthropological Institute. Prof. R. A. Fisher pointed out the value of such a centre for the reception of unpublished results and of the details of observations where these were too extensive for full publication. He stressed the importance of starting such a centre as soon as possible. Dr. A. Allison suggested that the centre should actively initiate or suggest new researches, and considered that fieldwork should to a large extent be decentralized.

Several speakers pointed out the difficulty of the techniques and the rarity of many of the necessary testing sera, both of which factors would for some years to come make it necessary for much of the work to continue to be done in a few central laboratories, the specimens being sent to them by air in most cases. Dr. ( ${ }^{x}$. Discombe considered that the stages of any decentralization should be under close control by workers who thernselves understood the tests and their difficulties.

The use of existing and future transfusion service records was next considered, and Dr. W. d'A. Maycock described the nature of the records of the National Blood Transfusion Service of England and Wales, and their anthropological value, pointing out the need for guarding against certain statistical errors which might arise if great care were not exercised in using the records for anthropological purposes.

The final topic was the systematization and use of existing published records. Dr. A. E. Mourant pointed to the rapid rate at which material is being published, scattered in very numerous journals, many of which are not readily accessible. $\mathrm{H}_{\theta}$ considered that this material, especially that published since Dr. W. C. Boyd's compilation of 1939 , should be collected, tabulated and published with uniform statistical treatment. This would occupy the whole time of at least one worker.

Prof. H. J. Fleure then proposed that the Council of the Royal Anthropological Institute should be asked to set up a committee to consider and make recommendations on the use of blood groups in anthropology. This proposition was accepted unanimously.

\section{OBITUARIES}

\section{Mr. William Williamson}

IT is in the tradition of British natural history that the only monograph on the water-mites of this country--the Ray Socioty's three volumes on "The British Hydracarina"- should have been written by two amateur naturalists, C. D. Soar and William Williamson. Williamson, born in Leith in June 1869, was during practically the whole of his working life a clerk, and latterly chief clerk, in the Scottish American Mortgage Company in Edinburgh. His interest in natural history began fortuitously, on 